\title{
PENGEMBANGAN KETERAMPILAN PROSES SAINS SISWA MENGGUNAKAN METODE INKUIRI TERBIMBING BERBASIS PORTOFOLIO SISWA SMA NEGERI 1 PURBOLINGGO
}

\section{Triana Asih}

\author{
Pendidikan Biologi FKIP Universitas Muhammadiyah Metro \\ E_mail :asih.triana@yahoo.com
}

\begin{abstract}
Biology learning should emphasize the provision of direct experience and at this time, using idelly scinence process skills (SPS). But on the subject of research, the lack of provision direct experience during the learning process and there is no provision of SPS in a structure way. Thus, the research applied the method of an inquiry guided based-portfolio, a method own answer to exsiting problems by using sins process skills. The conclusions in this study is the application of an inquiry guided based-portfolio to develop students scinence process skills classes $\mathrm{X}_{4}$ semsester odd Sinior High School 1 Purbolinggo year 2011/2012. The development can be observed from the increase as follows: the skills to make hypothesis or pre-CAR by $6,5 \%$ to $72,4 \%$ after the study, acquire skill and process data from the pre-CAR by $48,8 \%$ after the study to $80,6 \%$, communicating skills pre-CAR by $6,5 \%$ after the study to $82 \%$, and concluded at a rate skills of pre-CAR by $9,8 \%$ after the study to $78,7 \%$.
\end{abstract}

Kata kunci: Inkuiri Terbimbing, Portofolio, Keterampilan Proses Sains

Biologi sebagai salah satu bidang IPA menyediakan pengalaman belajar untuk memahami konsep dan keterampilan proses sains. Keterampilan proses sains ini meliputi keterampilan dasar dan keterampilan proses terpadu seperti mengamati, mengajukan hipotesis, menggunakan alat dan bahan secara baik dan benar dengan selalu mempertimbangkan keamanan dan keselamatan kerja, mengajukan pertanyaan, menggolongkan dan menafsirkan data, serta mengkomunikasikan hasil temuan secara lisan atau tertulis, menggali dan memilah informasi faktual yang relevan untuk menguji gagasan-gagasan atau memecahkan masalah sehari-hari (kontekstual). Hal ini berarti, melalui pembelajaran biologi sebagai salah satu Ilmu Pengetahuan Alam (IPA) di sekolah, semestinya dapat digunakan untuk membentuk kemampuan yang utuh, dalam arti mempunyai sikap, kemampuan kognitif, dan keterampilan memecahkan masalah yang dihadapi (Muhfahroyin: 2010)

Dimyati dan Mudjiono (2005) menyebutkan bahwa Keterampilan proses dasar meliputi kegiatan yang berhubungan dengan observasi, klasifikasi, pengukuran, komunikasi, prediksi, inferensi. Dan keterampilan terintegrasi meliputi identivikasi variabel, tabulasi, grafik, deskripsi hubungan variabel, perolehan dan proses data, analisis penyelidikan, hipotesis, dan eksperimen. 
Selanjutnya menurut Rustaman (2005), keterampilan proses perlu dikembangkan melalui pengalaman-pengalaman langsung sebagai pengalaman pembelajaran. Melalui pengalaman langsung seseorang dapat lebih menghayati proses atau kegiatan yang sedang dilakukan. Aspek-aspek kemampuan yang dikembangkan dalam keterampilan proses sains dalam adalah: mengamati, mengelompokan,menafsirkan/interpretasi, meramalkan, mengajukan pertanyaan, berhipotesis, merencanakan percobaan, menggunakan alat atau bahan, menerapkan konsep dan berkomunikasi. Berikut ini disajikan jenis-jenis indikator keterampilan proses sains beserta sub indikatornya.

\section{Tabel 1. Indikator dan Sub Indikator Keterampilan Proses Sains}

\begin{tabular}{|c|c|c|}
\hline No & $\begin{array}{l}\text { Indikator } \\
\text { Keterampilan } \\
\text { Proses Sains }\end{array}$ & Sub Indikator Keterampilan Proses Sains \\
\hline 1. & Mengamati & $\begin{array}{l}\text { - Menggunakan sebanyak mungkin alat indera } \\
\text { - Mengumpulkan/menggunakan fakta yang relevan }\end{array}$ \\
\hline 2. & $\begin{array}{l}\text { Mengelompo } \\
\text { kan/ } \\
\text { Klasifikasi }\end{array}$ & $\begin{array}{l}\text { - Mencatat setiap pengamatan secara terpisah } \\
\text { - Mencari perbedaan, persamaan } \\
\text { - Mengontraskan ciri-ciri } \\
\text { - Membandingkan } \\
\text { - Mencari dasar pengelompokkan atau penggolongan }\end{array}$ \\
\hline 3. & Menafsirkan & $\begin{array}{l}\text { - Menghubungkan hasil-hasil pengamatan } \\
\text { - Menemukan pola dalam suatu seri pengamatan } \\
\text { - Menyimpulkan }\end{array}$ \\
\hline 4. & Meramalkan & $\begin{array}{l}\text { - Menggunakan pola-pola hasil pengamatan } \\
\text { - Mengungkapkan apa yang mungkin terjadi pada keadaan yang } \\
\text { belum diamati }\end{array}$ \\
\hline 5. & $\begin{array}{l}\text { Mengajukan } \\
\text { Pertanyaan }\end{array}$ & $\begin{array}{l}\text { - Bertanya apa, mengapa, dan bagaimana. } \\
\text { - Bertanya untuk meminta penjelasan. } \\
\text { - Mengajukan pertanyaan yang berlatar belakang hipotesis. }\end{array}$ \\
\hline 6. & $\begin{array}{l}\text { Merumusakan } \\
\text { Hipotesis }\end{array}$ & $\begin{array}{l}\text { - Mengetahui bahwa ada lebih dari satu kemungkinan penjelasan } \\
\text { dari suatu kejadian. } \\
\text { - Menyadari bahwa suatu penjelasan perlu diuji kebenarannya } \\
\text { dengan memperoleh bukti lebih banyak atau melakukan cara } \\
\text { pemecahan masalah. } \\
\text {-Memperoleh berdasarkan teori yang ada }\end{array}$ \\
\hline 7. & $\begin{array}{l}\text { Merencanakan } \\
\text { Percobaan }\end{array}$ & $\begin{array}{l}\text { - Menentukan alat/bahan/sumber yang akan digunakan } \\
\text { - Mentukan variabel/ faktor penentu. } \\
\text { - Menetukan apa yang akan diukur, diamati, dicatat. } \\
\text { - Menentukan apa yang akan dilaksanakan berupa langkah kerja }\end{array}$ \\
\hline 8. & $\begin{array}{l}\text { Menggunakan } \\
\text { alat/bahan }\end{array}$ & $\begin{array}{l}\text { - Memakai alat/bahan } \\
\text { - Mengetahui alasan mengapa menggunakan alat/bahan. } \\
\text { - Mengetahui bagaimana menggunakan alat/ bahan. }\end{array}$ \\
\hline
\end{tabular}




\begin{tabular}{|c|c|c|}
\hline 9. & $\begin{array}{l}\text { Menerapkan } \\
\text { konsep }\end{array}$ & $\begin{array}{l}\text { - Menggunakan konsep yang telah dipelajari dalam situasi baru } \\
\text { - Menggunakan konsep pada pengalaman baru untuk menjelaskan } \\
\text { apa yang sedang terjadi }\end{array}$ \\
\hline 10. & Berkomunikasi & $\begin{array}{l}\text { - Mengubah bentuk penyajian } \\
\text { - Menggambarkan data empiris hasil percobaan atau pengamatan } \\
\text { dengan grafik atau tabel atau diagram } \\
\text { - Menyusun dan menyampaikan laporan secara sistematis } \\
\text { - Menjelaskan hasil percobaan atau penelitian } \\
\text { - Membaca grafik atau tabel atau diagram. } \\
\text { - Mendiskusikan hasil kegiatan mengenai suatu masalah atau suatu } \\
\text { peristiwa. } \\
\text {-Mengutarakan suatu gagasan }\end{array}$ \\
\hline
\end{tabular}

Berdasarkan pengamatan hasil prasurvei, terungkap bahwa guru belum pernah merancang pembelajaran untuk membangun keterampilan proses sains (KPS) secara terstruktur. Beberapa KPS yang sering dikembangkan dalam pembelajaran tetapi secara spontan seperti kemampuan membuat hipotesis atau membuat prediksi atas masalah yang ada, kemampuan memproses dan mengolah data, kemampuan mengkomunikasikan, dan menyimpukan dirasakan masih sangat perlu untuk ditingkatkan.

Berdasarkan pengalaman tersebut, peneliti melakukan diskusi dengan guru biologi yang mengajar di kelas $\mathrm{X}_{4}$ untuk melakukan identifikasi masalah serta penyebab timbulnya masalah tersebut. Diskusi menghasilkan beberapa temuan yang menunjukkan bahwa indikasi keterampilan proses yang rendah dapat dilihat dari: a) hanya 6,5 \% dari 31 siswa yang dapat memprediksi atau mengajukan pendapat atas masalah yang ada; b) hanya 48,4 \% dari 31 siswa yang mampu mengerjakan tugas dengan benar; c) hanya 6,5 \% dari 31 siswa yang mampu mengungkapkan pendapat; d) hanya 9,8 \% dari 31 siswa yang berani menyimpulkan kegiatan pembelajaran. Dan jumlah siswa yang lulus murni dalam mencapai standar kompetensi dan kompetensi dasar yaitu 45\% dari 31 orang siswa.

Kemudian peneliti berdiskusi dengan guru merencanakan solusi dan tindakan untuk menyelesaikan permasalahan tersebut. Akhirnya disepakati bahwa perlu ada perubahan yang mendasar terhadap strategi pembelajaran yang digunakan guru dalam pembelajaran biologi. Dalam hal ini yang dipilih yaitu pembelajaran menggunakan pendekatan keterampilan proses sains melalui metode inkuiri terbimbing berbasis portofolio. Karena dengan diterapkannya metode inkuiri terbimbing berbasis portofolio maka siswa akan mengalami pengalaman secara langsung dengan menemukan sendiri jawaban-jawaban atas permasalahan yang ingin dicari sehingga akan memperoleh pemahaman yang lebih mendalam dan memungkinkan siswa untuk dapat menyelesaikan berbagai tugas-tugas akademik. Dengan demikian, tujuan dari penelitian ini adalah Untuk mengembangkan keterampilan proses sains Biologi siswa kelas $\mathrm{X}_{4}$ SMA $\mathrm{N} 1$ Purbolinggo dengan menggunakan metode inkuiri terbimbing berbasis portofolio. 


\section{METODE}

Penelitian ini merupakan penelitian tindakan kelas yang dilaksanakan pada semester ganjil tahun pelajaran 2011/2012 pada siswa SMA Negeri 1 Purbolinggo pada standar kompetensi memahami kegunaan bahan kimia dalam kehidupan, dengan kompetensi dasar Siswa mampu memahami prinsip-prinsip pengelompokan makhluk hidup. Penelitian tindakan kelas ini dilaksanakan dalam 2 siklus yang meliputi tahap-tahap dalam penelitian yaitu : 1) perencanaan, 2) pelaksanaan tindakan, 3) observasi dan evaluasi tindakan, dan 4) refleksi dari perjalanan setiap pertemuan yang dilaksanakan selama pembelajaran. Pembelajaran dilaksanakan selama 2 kali pertemuan dengan alokasi waktu setiap pertemuan (2 x 45 menit) sedangkan penelitian dilaksanakan mulai tanggal 14 November sampai dengan 25 November 2011. Penelitian dilaksanakan di SMA Negeri 1 Purbolinggo Lampung-timur pada semester ganjil tahun pelajaran 2011/2012 dengan subjek penelitian siswa $\mathrm{X}_{4}$ dengan jumlah siswa 27 siswa dengan tingkat kemampuan yang beragam. Sedangkan objek penelitian metode inkuiri terbimbing berbasis portofolio dalam mengembangkan keterampilan proses sains siswa.

Dalam penelitian, peneliti melakukan tahap penelitian dengan mengkaji materi yang akan dilakukan selama pembelajaran dalam penelitian, setelah itu mempersiapkan segala perangkat pembelajaran yang akan digunakan selama penelitian seperti silabus, rencana pelaksanaan pembelajaran serta lembar kerja siswa (LKS) sebagai evaluasi penilaian KPS. Dalam tahap pelaksanaan, peneliti melaksanaan pembelajaran dengan metode inkuiri terbimbing berbasis portofolio dan mengamati keterampilan proses sains. Pada setiap pertemuan, peneliti memberikan LKS yang telah didesain sesuai dengan langkah-langkah metode inkuiri terbimbing berbasis portofolio agar diperoleh data KPS siswa. Dengan langkah-langkah sebagai berikut:

1) Guru menyampaikan tujuan pembelajaran dan memotivasi siswa tentang belajar dengan integrasi inkuiri terbimbing berbasis portofolio.

2) Guru membagi kelompok menjadi 6 kelompok, terdiri dari 4-5 orang secara heterogen.

3) Guru menyajikan pertanyaan atau masalah

4) Guru membimbing siswa dalam menentukan hipotesis yang relevan dengan permasalahan dan memprioritaskan hipotesis mana yang menjadi prioritas penyelidikan.

5) Guru menyuruh siswa secara berkelompok melakukan pengamatan.

6) Siswa memperoleh informasi berdasarkan hasil pengamatannya dan merangkum hasil temuannya pada kertas sebagai bahan portofolio. 
7) Kegiatan selanjutnya guru menyuruh siswa secara berkelompok untuk mengkomunikasikan dan menyimpulkan hasil pengamatan yang sudah terangkum.

Pada tahap terakhir adalah refleksi dilakukan pada setiap akhir pertemuan dan akhir siklus dalam menkaji pembelajaran yang dilakukan.

Tindakan penelitian dikatakan berhasil apabila persentase setiap keterampilan telah mencapai target. Adapun target keterampilan proses yang akan dicapai dalam penelitian ini adalah :

\section{Tabel 2. Indikator Aspek Keterampilan Proses Sains yang diamati}

\begin{tabular}{|l|l|l|}
\hline No & Aspek yang dinilai & Target yang ingin dicapai \\
\hline 1 & Membuat hipotesis & $70 \%$ \\
\hline 2 & $\begin{array}{l}\text { Memperoleh dan memproses } \\
\text { data }\end{array}$ & $80 \%$ \\
\hline 3 & Mengkomunikasikan & $80 \%$ \\
\hline 4 & Menyimpulkan & $70 \%$ \\
\hline
\end{tabular}

\section{HASIL}

Keterampilan proses sains siswa kelas $\mathrm{X}_{4}$ semsester ganjil SMA Negeri 1 Purbolinggo Tahun Pelajaran 2011/2012 pada materi pokok fungi (jamur) dapat dilihat dari peningkatan sebagai berikut: keterampilan membuat hipotesis dari pra PTK sebesar 6,5\% setelah penelitian dari 69,9\% menjadi 72,4\%, keterampilan memperoleh dan memproses data dari pra PTK sebesar 48,4\% setelah penelitian dari 72,3\% menjadi 80,6\%, keterampilan mengkomunikasikan dari pra PTK sebesar 6,5\% setelah penelitian 73,4\% menjadi 82\%, serta keterampilan menyimpulkan sebesar dari pra PTK sebesar 9,8\% setelah penelitian dari 71,5\% menjadi 78,7\%. Berdasarkan hasil pengamatan keterampilan proses sains tersebut, maka dapat dilihat pengembangan keterampilan proses sains siswa dalam diagram berikut: 


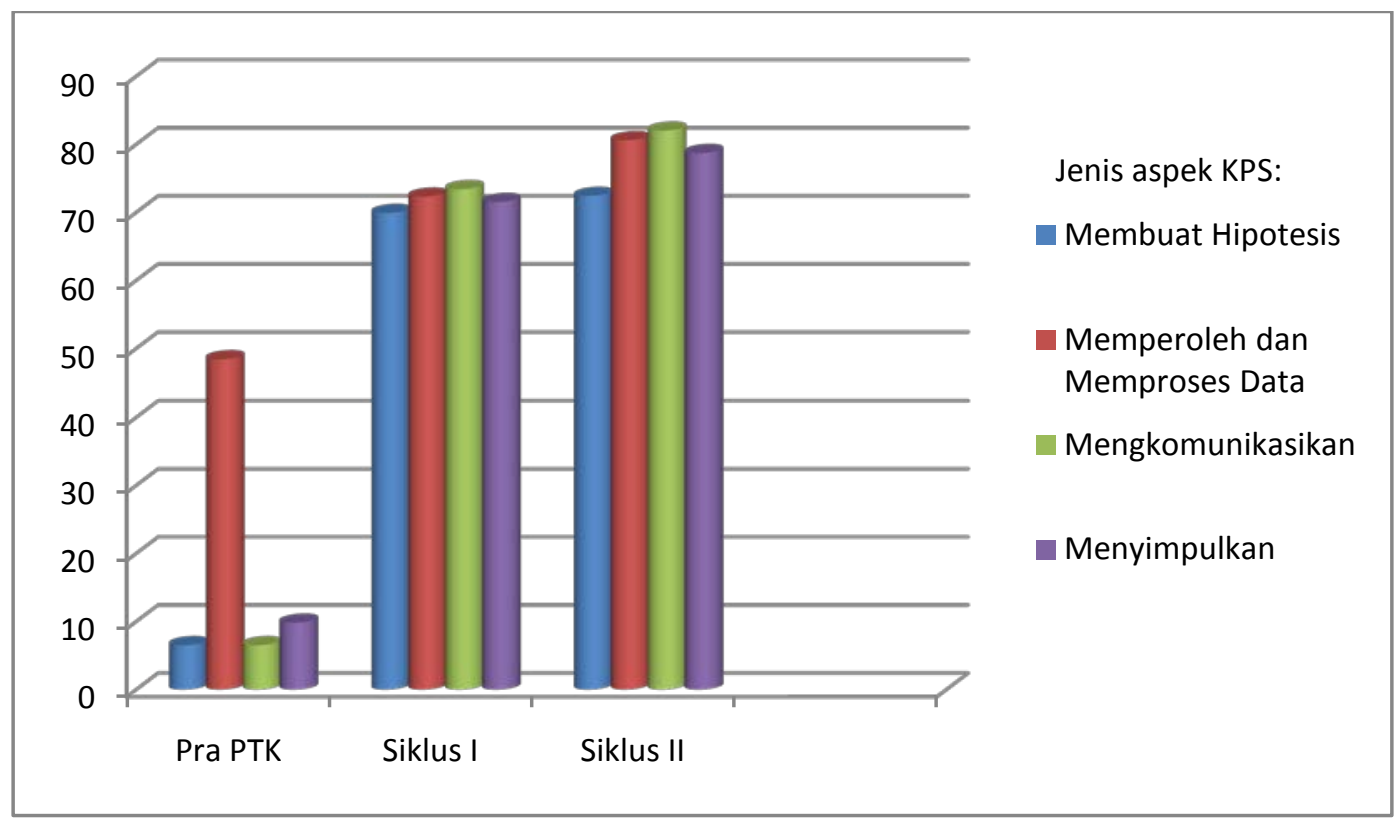

Gambar 1. Perkembangan Keterampilan Proses Sains Siswa

\section{PEMBAHASAN}

Pembelajaran inkuiri terbimbing mengajak siswa melakukan serangkaian kegiatan fisik maupun mental (kognitif). Siswa diminta untuk memahami atau merumuskan: masalah, tujuan, dan hipotesis. Siswa melakukan pengamatan atau penyelidikan, mencari data, menganalisis permasalahan yang telah dirumuskan. Santoso (2010:155-156). Dan pemberian tugas dalam bentuk portofolio juga dapat membantu mengembangkan keterampilan siswa dalam memproses data yaitu merangkum kembali kedalam tugas harian. Menurut Budimansyah (2003:9), portofolio merupakan kumpulan hasil belajar peserta didik. Portofolio, selain sangat bermanfaat dalam memberikan informasi mengenai kemampuan dan pemahaman siswa serta memberikan gambaran-gambaran mengenai sikap dan minat siswa terhadap pelajaran yang diberikan, juga menunjukan pencapaian atau peningkatan yang diperoleh dari proses pembelajaran (Mangoesaputro, 2004:1)

Peningkatan keterampilan proses sains tersebut dapat terukur melalui rubik penilaian yang mencangkup kriteria-kriteria sebagai berikut: 
Tabel 3. Kriteria Penilaian Keterampilan Proses Sains

\begin{tabular}{|c|c|c|c|c|c|}
\hline \multirow[t]{2}{*}{ No. } & \multirow[t]{2}{*}{ Kriteria } & \multicolumn{4}{|c|}{ Kategori kemampuan } \\
\hline & & (sangat baik) & (baik) & (cukup) & (kurang) \\
\hline 1 & $\begin{array}{l}\text { Membuat } \\
\text { hipotesis }\end{array}$ & $\begin{array}{l}\text { Memprediksi } \\
\text { dengan benar, } \\
\text { berdasarkan teori, } \\
\text { dan membuat } \\
\text { hipotesis. }\end{array}$ & $\begin{array}{l}\text { Memprediksi } \\
\text { dengan benar, } \\
\text { berdasarkan } \\
\text { teori. }\end{array}$ & $\begin{array}{l}\text { Memprediksi } \\
\text { dengan } \\
\text { beberapa teori. }\end{array}$ & $\begin{array}{l}\text { Menebak- } \\
\text { nebak. }\end{array}$ \\
\hline 2 & $\begin{array}{l}\text { Memperoleh dan } \\
\text { memproses data }\end{array}$ & $\begin{array}{l}\text { Memperoleh data } \\
\text { secara sistematis, } \\
\text { dari hasil } \\
\text { pengamatan, dan } \\
\text { menuliskan data }\end{array}$ & $\begin{array}{l}\text { Memperoleh } \\
\text { data secara } \\
\text { sistematis dari } \\
\text { hasil } \\
\text { pengamatan }\end{array}$ & $\begin{array}{l}\text { Memperoleh } \\
\text { data secara } \\
\text { sistematis dari } \\
\text { beberapa hasil } \\
\text { pengamatan }\end{array}$ & $\begin{array}{l}\text { Perolehan } \\
\text { data tidak } \\
\text { benar }\end{array}$ \\
\hline 3 & $\begin{array}{l}\text { Mengkomuni- } \\
\text { Kasikan }\end{array}$ & $\begin{array}{l}\text { Menyampaikan } \\
\text { secara sistematis, } \\
\text { data hasil } \\
\text { pengindraan, dan } \\
\text { mengutarakan } \\
\text { suatu gagasan }\end{array}$ & $\begin{array}{l}\text { Menyampai- } \\
\text { kan secara } \\
\text { sistematis data } \\
\text { hasil } \\
\text { pengindraan }\end{array}$ & $\begin{array}{l}\text { Menyampai- } \\
\text { kan } \\
\text { beberapa data } \\
\text { hasil } \\
\text { pengindraan }\end{array}$ & $\begin{array}{l}\text { Menyampai- } \\
\text { kan data } \\
\text { tidak jelas }\end{array}$ \\
\hline 4 & Menyimpulkan & $\begin{array}{l}\text { Tampak } \\
\text { memahami } \\
\text { konsep, } \\
\text { berdasarkan } \\
\text { perolehan dan } \\
\text { membuat } \\
\text { kesimpulan }\end{array}$ & $\begin{array}{l}\text { Tampak } \\
\text { memahami } \\
\text { konsep } \\
\text { berdasarkan } \\
\text { perolehan } \\
\text { yang telah } \\
\text { dipelajari }\end{array}$ & $\begin{array}{l}\text { Tampak } \\
\text { memahami } \\
\text { beberapa } \\
\text { konsep yang } \\
\text { telah } \\
\text { dipelajari. }\end{array}$ & $\begin{array}{l}\text { Tidak ada } \\
\text { kesimpulan } \\
\text { atau tampak } \\
\text { miskonsepsi }\end{array}$ \\
\hline
\end{tabular}

Dengan skala kategori kemampuan:

Tabel 4. Skala Kategori Kemampuan

\begin{tabular}{|c|c|}
\hline Nilai \% & Kategori Kemampuan \\
\hline $75-100 \%$ & Sangat Baik \\
$50-74 \%$ & Baik \\
$25-49 \%$ & Cukup \\
$<25 \%$ & Kurang \\
\hline
\end{tabular}

(Riduwan, 2005:18)

Berdasarkan kriteria penilaian KPS tsb, maka pengembangan keterampilan proses sains siswa kelas $\mathrm{X}_{4}$ dapat dilihat mulai dari siklus I yaitu keterampilan membuat hipotesis memiliki persentase 69,9\% termasuk kategori baik, keterampilan memperoleh dan memproses data memiliki persentase 71,8\% termasuk kategori baik. Pada keterampilan mengkomunikasikan memiliki persentase paling tinggi yaitu 73,4\% termasuk kategori baik. Dan menyimpulakan memiliki persentase $71,5 \%$ dengan kategori baik. Dan mengalami peningkatan 
pada siklus II yaitu Keterampilan membuat hipotesis mencapai 72,4\% termasuk kategori baik, pada keterampilan memperoleh dan memproses data mencapai 80,6\% yang termasuk kategori sangat baik, keterampilan mengkomunikasikan mencapai $82 \%$ yang termasuk kategori sangat baik, serta keterampilan menyimpulkan mencapai 78,7\% yang termasuk kategori sangat baik.

Seperti yang diungkapakan oleh Gulo (2005), salah satu keuntungan dari metode inkuiri adalah mendorong pelajar berpikir dan merumuskan hipotesis serta membuktikannya melalui proses belajar. Pada saat proses belajar, siswa melakukan pengamatan pada objek langsung, baik objek nyata yaitu macammacam objek jamur yang akan diamati, maupun pada gambar yang telah didesain langsung oleh guru. Pada langkah sebelumnya, yaitu membuat hipotesis missal “Jamur tidak memiliki klorofil” maka siswa memperoleh data melalui proses pengamatan langsung objek yang ada seperti jamur tiram, jamur tempe, jamur oncom, serta berbagai jenis jamur yang ada pada gambar di LKS. Dari hasil pengamatan tersebut, siswa dapat mengamati bahwa semua jenis jamur tersebut tidak ada yang berwarna hijau, yang berarti tidak memiliki zat hijau daun yang disebut dengan klorofil. Maka siswa memperoleh informasi, kemudian memproses data tersebut. Keterampilan proses selanjutnya yaitu keterampilan mengkomunikasikan yang dimaksud adalah keterampilan siswa dalam menyampaikan perolehan secara sistematis dari data hasil pengindraan, dan dapat mengutarakan suatu gagasan. Keterampilan menyampaikan perolehan ditunjukan ketika siswa melakukan kegiatan presentasi didepan kelas dalam bentuk lisan, tulisan, gerak atau gambar. Hal ini sesuai pendapat Dimyati dan Mudjiono (1999) Keterampilan menyampaikan sesuatu secara lisan maupun tulisan termasuk komunikasi. Mengkomunikasikan dapat diartikan sebagai penyampaikan dan memperoleh fakta, konsep, dan prinsip ilmu pengetahuan dalam bentuk suara, visual, atau suara dan visual. Sedangkan mengutarakan pendapat ditunjukan dengan penyampaian suatu ide atas perolehannya dari hasil pengamatan kepada orang lain. Keterampilan proses selanjutnya yaitu Keterampilan menyimpulkan yang dimaksud adalah keterampilan yang ditunjukan dari pemahaman siswa terhadap materi perolehan yang telah dipelajari sehingga dapat membuat suatu kesimpulan. Gulo (2005) berpendapat langkah penutup dalam pembelajaran inkuiri adalah membuat kesimpulan berdasarkan data yang diperoleh siswa. Sebelum dilakukan pembelajaran inkuiri, terlebih dahulu harus dilakukan kegiatan pendahuluan. Hal ini untuk mengaitkan materi yang telah diperoleh siswa dengan materi yang akan dipelajari. Dengan demikian, siswa tidak akan merasa asing dengan pelajaran dan dapat merangsang keingintahuan siswa.

Dengan demikian penggunakan metode inkuiri terbimbing berbasis portofolio dapat mengembangkan keterampilan proses sains yang pada dasarnya keterampilan proses sains ini sudah dimiliki oleh peserta didik. Sehingga, keterampilan proses sains dapat meningkat. 


\section{KESIMPULAN dan SARAN \\ Kesimpulan}

Berdasarkan hasil penelitian yang dilakukan, dapat disimpulkan bahwa: Metode inkuiri terbimbing berbasis portofolio dapat mengembangkan keterampilan proses sains siswa kelas $\mathrm{X}_{4}$ SMA Negeri 1 Purbolinggo Tahun Pelajaran 2011/2012.

\section{Saran}

Berdasarkan kesimpulan penelitian ini, maka peneliti menyarankan:

1. Bagi guru. Untuk meningkatkan keterampilan proses siswa pada materi fungi (jamur), maka guru dapat menerapkan metode inkuiri terbimbing berbasis portofolio.

2. Bagi siswa. Siswa bersungguh-sungguh dalam pelaksanaan pembelajaran serta melakukan setiap keterampilan proses sains dengan baik agar hasil yang diperoleh pun baik.

\section{DAFTAR RUJUKAN}

Budimansyah, Dasim. 2003. Model Pembelajaran Berbasis Portofolio Biologi. Bandung: PT Genesindo.

Dimyati dan Mudjiono. 1999. Belajar Dan Pembelajaran. Jakarta: Rineka Cipta.

_. 2005. Belajar Dan Pembelajaran. Jakarta: Rineka Cipta.

Gulo, W. 2005. Strategi Belajar Mengajar. Jakarta: grasindo.

Mangkoesaputro, arief. 2004. Model Pembelajaran Portofolio Sebuah Tinjauan Kritis. Arif_Mangkoesaputro@yahoo.com. (13 Mei 2010).

Muhfahroyin. 2010. Telaah Biologi SMA. Metro: Publishing.

Riduwan.2005. Rumus dan Data dalam Analisis Stattistika. Bandung: Alfabeta.

Rustaman, Nuryani. 2005. Strategi Belajar Mengajar Biologi Malang: UM Press.

Santoso, Handoko. 2010. Pengaruh Cooperative Learning Dipadu Inquiry terhadap Kemampuan Berpikir Kritis Siswa SMA Berkemampuan Atas dan Bawah di Kota Metro. Bioedukasi Jurnal Pendidikan biologi FKIP UM Metro.2. 90-178. 